\title{
In memoriam \\ Leon Eisenberg and the essence of Medicine
}

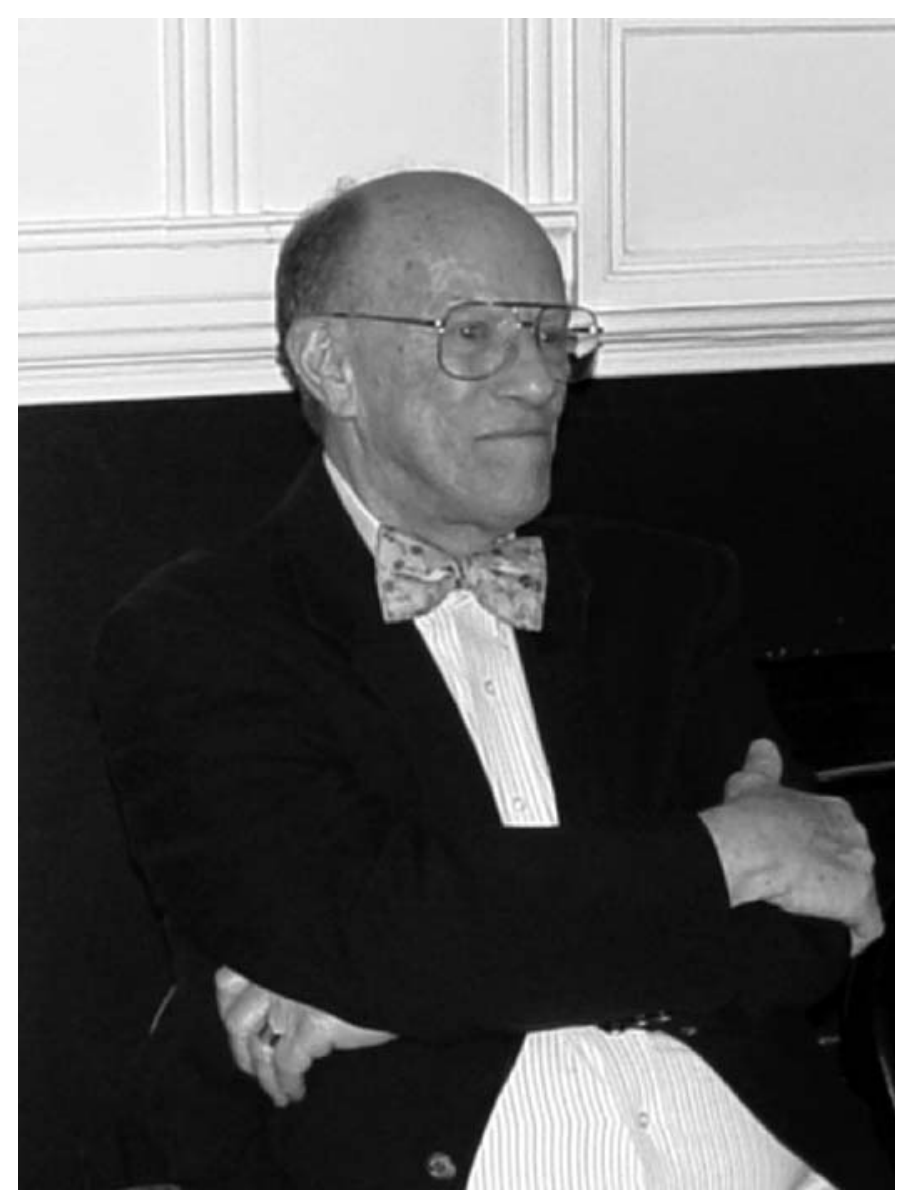

I got in touch with Leon Eisenberg at the very end of his long and fulfilling professional life, or, to be precise, he got in touch with me. On December $12^{\text {th }}, 2006$ I received a sharp and hilarious comment on a paper I had written on the change of the name "mental retardation" to "intellectual disability" and its relation to stigma. In a friendly tone, it distilled joy of life and "bonheur". The author recalled an old editorial at the American Journal of Psychiatry which explained that soldiers with neuropsychiatric problems were classified under a code known as 'Section 8' during the Second World War. "In no time at all, this classification number spread throughout the military community and became a term of derision. If you were thought to be a bit odd, you were called a 'Section 8'. Army psychiatrists concerned about the stigma changed the terminology from "Section 8" to "Simple Adult Maladjustment". Not long after the change was made, the author of the editorial was in a base camp watching a film starring Jerry Lewis. He was astonished to hear members of the audience call out "Look at the 'Sammy'. After a moment he realized that "Sammy" stemmed from the initial letters "S.A.M." of "Simple Adult Maladjustment".

When I reached the end of the last line I was surprised to find out that the author was Leon Eisenberg. By the time I received this email, I had admired him for many

Epidemiologia e Psichiatria Sociale, 19, 1, 2010 
years. He was a talented polymath in a time of super-specialisation in Medicine. Had he persisted in the study of autism or other areas he worked on, he most likely would have won the Nobel Prize. Nevertheless his contribution to Medicine could not have been greater. His restless mind moved from one field to another without slowing: From the standardised assessment of autism to randomised clinical trials in psychopharmacology, which he started in 1962. From diagnosis and treatment of ADHD to the first effectiveness study in mental health service research. From the first RCT on psychotherapy to psychiatric diagnosis and treatment in primary care. He moved back and forth between neurosciences and social care, between genetics and environment, and between research and policy, never forgetting to return to the basic concepts of disease, resilience, global health, and a constant concern about the improvement of medical education, human rights and equal opportunities.

Certainly, the vast interests of Leon Eisenberg exceeded all the standards of conventional academia; however he excelled in all of them. He was also a man of strong convictions. After an enthralling email exchange, we finally met in 2008. He expressed his concern about the role of pharmaceutical companies in Medicine and how to prevent related conflicts of interests. He included this topic in his last speech at the 2008 World Psychiatric Congress when he received the WPA Lopez-Ibor Award. This warning about ethics (Eisemberg, 2009), in which he urged us to "join the crusade to return medicine to its fundamental values", together with his approach to integra- tive care in child and adolescent psychiatry (Eisenberg \& Belfer, 2009) were his last contributions to our specialty.

The loss of Leon Eisenberg is a great loss for Medicine but it is even greater for social psychiatry. His final paper on the current role of social medicine is a seminal one. It concludes by saying that "if we want to fulfil our role as medical professionals, we cannot confine our alleviation of suffering to patient biology. Our bedside manner should be extended to an informed 'community-side manner' that considers all the social contributing factors to human health" (Holz et al., 2006).

The first email I received from Leon Eisenberg finished by saying that the old editorial was entitled "A rose by any other name". As though inspired by Shakespeare's verse, Leon Eisenberg's mind was always concerned about the essence of Medicine. ${ }^{1}$

Luis Salvador-Carulla

Professor of Psychiatry. University of Cadiz (Spain) Vice-president. Spanish Society of Psychiatric Epidemiology luis.salvador.telefonica.net

\section{REFERENCES}

Eisenberg L. (2009). [Psychiatry and human rights: putting the good of the patient first]. Actas Espanolas de Psiquiatria 37, 1-8.

Eisenberg L. \& Belfer M. (2009). Prerequisites for global child and adolescent mental health. Child Psychology and Psychiatry 50, 26-35.

Holtz T.H., Holmes S.M., Stonington S. \& Eisenberg L. (2006). Health is still social: contemporary examples in the age of the genome. PLoS Medicine 3, e419. 